\title{
STRATEGI KEBERLANJUTAN EKONOMI MASYARAKAT NELAYAN DI DESA MASADIAN KECAMATAN MENUI KEPULAUAN KABUPATEN MOROWALI
}

Hasrianti Amiludin ${ }^{1}$, Wa Ode Sifatu ${ }^{2}$, Ratna Supiyah ${ }^{3}$

${ }^{123}$ Universitas Halu Oleo

\section{d.}

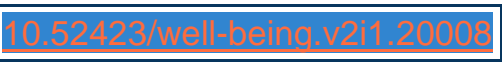

ABSTRACT

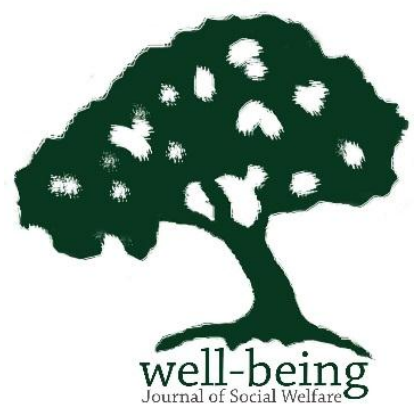

The purpose of this study was to determine the sustainability strategies for the economic livelihoods of indigenous people in Masadian Village, Menui District, Morowali Regency and strategies for increasing the economy of the puppet community in Desa Santas, Menadian District, Menow Islands, Morowali Regency. The results of the study showed that solving the problem of economic sustainability in the Desa Desa community uses an active strategy in which all communities express their daily needs by doing side jobs with various forms of work such as working as construction workers, ship / boatbuilders, fish buyers. The side jobs that are most chosen by fishermen are construction workers and shipbuilders and poverty reduction models with a participatory approach or the role of the wife / children to help the husband work

Keywords: Strategy, Economic Sustainability, Society, Fishermen

\section{PENDAHULUAN}

Wilayah pesisir adalah daerah pertemuan antara darat dan laut. Jika ke arah darat wilayah bagian daratan, baik kering maupun terendam air, yang masih dipengaruhi oleh sifat- sifatlaut,seperti pasang surut,angin laut dan perembesan air asin.Sedangkan ke arahlaut,wilayah pesisir mencakup bagian laut yang masih dipengaruhi oleh proses alami yang terjadi didarat, seperti sedimentasi dan aliran air tawar, maupun yang disebabkan karena kegiatan manusia di darat, seperti penggundulan hutan dan pencemaran (Christanto,

$$
\text { 2010). }
$$

Indonesia merupakan Negara maritim yang memiliki luas perairan mencapai 3,25 juta $\mathrm{km} 2$ atau sekitar 63 persen wilayah Indonesia. Laut Indonesia memiliki potensi produksi lestari ikan laut yangcukup besar, dengan asumsi sekitar 6,51juta ton/tahun atau 8,2\% dari total potensi produksi ikan laut dunia. Statistik Perikanan Tangkap (2011) menunjukkan terdapat 2,7 juta jiwa nelayan dan Statistik Perikanan Budi daya (2011) menunjukkan jumlah pembudi dayaikan mencapai 3,3 juta. Sedangkan Sensus Pertanian yang dilakukan BPS pada tahun 2013, menunjukkan jumlah 860 ribu rumah tangga kegiatan penangkapan ikan (nelayan)dan1,19juta rumahtangga kegiatanbudidaya ikan. Apakah perbedaan data antara tahun 2011 dan 2013 disebabkan terjadi migrasi pekerjaan dari sektor perikanan (khususnya nelayan) ke sektor lain atau perbedaan metode. Ratarata pendapatan nelayan dari hasil tangkapan di laut asumsi potensi lestari telah dimanfaatkan sebagian hanya sebesar Rp

28,08 juta/tahun, lebih kecil dibandingkan pendapatan pembudidaya ikan diperairan umum dan ditambak yang mencapai Rp 34,80 juta/tahun dan Rp 31,32 juta/tahun. Namun, pendapatan nelayan yang menangkap ikan di laut lebih baik dibandingkan pendapatan pembudidaya ikan dilaut yang hanya memperoleh pendapatan sebesar Rp24,39 juta/tahun. Pendapatan rata-rata yang rendah tersebut menyebabkan nelayan dan pembudidaya ikan menjadi miskin dan 
terbatas memenuhi kebutuhan hidupnya. Dalam tataran praktis, kemiskinan nelayan dikarenakan pendapatannya lebih kecil daripada pengeluaran sehingga tidak mencukupi kebutuhan hidup keluarga. Pendapatan nelayan, khususnya nelayan kecil dan anak buah kapal (ABK) dari kapal ikan komersial /modern (diatas30GT) pada umumnya kecil (kurang dari $\mathrm{Rp} 1$ juta/bulan) dan sangat fluktuatif. Pendapatan nelayan yang rendah juga diikuti dengan tingkat pendidikan yang rendah dimana hampir $70 \%$ nelayan berpendidikan setingkat sekolah dasar kebawah, dan hanya sekitar1,3 persen yang berpendidikan tinggi.

Indonesia merupakan Negara Kepulauan dengan jumlah pulau yang mencapai 17.508 dan panjang garis pantai kurang lebih81.000Km (DKP,2008). Keadaan ini menyebabkan kawasan pesisir menjadiandalan sumber pendapatan masyarakat Indonesia. Kawasan pesisir sangat produktif dan mengandung potensi pembangunan yang tinggi $85 \%$ kehidupan biota laut tropis bergantung pada ekosistem pesisir dan $90 \%$ hasil tangkapan ikan berasal dari laut dangkal dan pesisir. Jadi, kawasan pesisir merupakan sasaran untuk pembangunan berkelanjutan (Christanto, 2010) Kawasan ini sangat kompleks dengan berbagai isu dan permasalahan yang memerlukan penanganan yang komprehensif dengan strategis khusus dan terpadu. Selama ini kawasan pesisir belum mendapat perhatian yang cukup serius baik dari

pemerintah, masyarakat maupun pihak ketiga dalam pengelolaannya, sehingga belakangan ini baru dirasakan berbagai permasalahan yang muncul tentang kawasan pesisir(BKKSI, 2001).

Pengalaman bangsa Indonesia dimasa lalu dalam membangun wilayah pesisir dan lautan menunjukkan hasil yang kurang optimal dan cenderung menuju kearah yang tidak berkelanjutan. Masyarakat nelayan sebagai komunitas wilayah pesisir, sering kali tersisih dari pembangunan sebab prioritas kebijakan pemerintah lebih terfokus kepada sektor pertanian atau daratan. Kehidupan nelayan yang masih menggantungkan nasib kepada hasil laut, masih dalam taraf sederhana dengan pola mata pencaharian menggunakan teknologi tradisional. Di samping alat tangkap mereka sudah jauh tertinggal, mereka melaut juga pada area penangkapan di wilayah pesisir juga terbatas. Masyarakat pesisir pada umumnya merupakan kelompok masyarakat yang relatif tertinggal secara sosial, ekonomi, dan cultural dibandingkan dengan kelompok masyarakat lain. Persepsi demikian didasarkan pada hasil pengamatan langsung terhadap realitas kehidupan masyarakat nelayan atau melalui pemahaman terhadap hasil-hasil kajian akademis. Keterbelakangan sosial ekonomi pada masyarakat pesisir merupakan hambatan potensial bagi mereka untuk mendorong dinamika pembangunan di wilayahnya. Akibatnya sering terjadi kelemahan bargaining position dengan pihak-pihak lain diluar kawasan pesisir, sehingga mereka kurang memiliki kemampuan mengembangkan kapasitas dirinya dan organisasi atau kelembagaan social yang dimiliki sebagai sarana aktualisasi dalam membangun wilayahnya (Kusnadi, 2006).

Berkaitan dengan kesejahteraan masyarakat pesisir, terdapat beberapa faktor yang menyebabkan mereka masih tertinggal antara lain keadaan sumberdaya alam yang semakin menipis, kurangnya budaya menabung dan mengelola keuangan keluarga, serta struktur ekonomi atau tataniaga yang belum kondusif bagi kemajuan dan 
kemakmuran nelayan (Rokhmin Dahuri dan Rais Ginting, 2001).

Pendapatan masyarakat ne layan secara langsung maupun tidakakan sangat mempengaruhi kualitas hidup mereka, karena pendapatan dari hasil berlayar merupakan sumber pemasukan uatama atau bahkan satu-satunya bagi mereka,sehingga besar kecilnya pendapatan akan sangat memberiakan pengaruh terhadap kehidupan mereka, terutama terhadap kemampuan mereka dalam mengelola lingkungan tempat hidup mereka. Pada saat musim kemarau ketika temperatur air laut cukup tinggi, ikan sulit diperoleh karena nelayan tidak melakukan penangkapan ikan maka mengakibatkan tingkat penghasilan nelayan menurun. Apabila diperairan pantai pesisir sedang tidak musim ikan atau tidak ada penghasilan yang baik, nelayan akan melakukan migrasi musiman kedarat yang dapat memberikan penghasilan, lama masa migrasi musiman nelayan pesisir tersebut sangat bergantung pada tingkat penghasilan yang ada, artinya jika tingkat penghasilan yang diperoleh dalam dua-tiga hari melaut dari masamasa akhir mereka sudah dianggap sedikit berarti mereka harus menyudahi masa andunnya. Kondisi ini sanga terat kaitannya dengan Desa Masadian yang merupakan daerah pesisir. Mata pencaharian masyarakat di Desa Masadian pada umumnya adalah sebagai nelayan karena di dukung oleh potensi alam disekitarnya yaitu kabupaten Morowali yang memiliki pesisir pantai yang panjang sekitar $+500 \mathrm{Km}$, dengan luas perairan laut sekitar 29.962,88 kilometer persegi. Fenomena yang

terjadi pada masyarakat pesisir pantai nelayan di Desa Masadian Kec. Menui Kepulauan Kabupaten Morowali adalah kondisi kehidupan perekonomian masyarakatnya selalu tidak pasti, kadang kala mereka dapat memenuhi kebutuhan hidupnya, kadang pula tidak, karena pendapatan yang mereka terima tidak seimbang dengan kebutuhan sehari-hari, sebab pendapatan nelayan sangat bergantung pada situasi dan kondisi alam. Kondisi alam yang tidak menentu, keberadaan ikan tidak menetap karena selalu berpindah-pindah dari satu temapat ketempat lain, dimana arus laut tidak stabil, adanya angin (baik angin timur, barat, barat laut dan barat daya) yang dapat menimbulkan ombak besar, fasilitas alat tangkap tidak memadai, harga BBM dan harga barang tinggi, serta adanya kerusakan mesin dan perahu bocor sehingga menyebabkan pendapatan paranelayan turun. Idealnya, potensi pesisir pantai yang panjang sekita +500 $\mathrm{Km}$, dengan luas perairan laut sekitar 29.962,88 kilometer persegi menjadi sumber daya alam yang dapat mendukung kesejahteraan hidup masyarakat nelayan. Namun kenyataannya saat ini para nelayan semakin kesulitan untuk menangkap ikan. Berdasarkan Latar Belakang Di Atas Penulis Tertarik Untuk Meneliti Dengan Judul "Strategi Keberlanjutan Ekonomi Masyarakat Nelayan Di Desa Masadian Kecamatan Menui Kepulauan Kabupaten Morowali".

\section{METODE PENELITIAN}

Penelitian ini dilakukan di Desa Masadian Kecamatan Menui Kepulauan Kabupaten Morowali Provinsi Sulawesi Tengah. Dalam penelitian penulis menggunakan tipe penelitian deskriptif kualitatif, yang mana penelitian berusaha mengkaji,menelaah dan juga dapat menguraikan data yang akan di dapat di lapangan yakni Strategi Keberlanjutan Ekonomi Masyarakat Nelayan Di Desa Masadian Kecamatan Menui Kepulauan Kabupaten Morowali. Dalam sebuah penelitian diperlukan orang-orang yang akan kita pilih sebagai pemberi informasi 
mengenai data yang kita perlukan. Adapun sumber data dalam penelitian ini sebanyak 10 orang, yang terdiri dari 3 orang Pemerintah Desa , 1 wirausaha, serta 6 orang masyarakat nelayan Desa Masadian. Sumber data primer dikumpulkan melalui investioner informan. Data primer dapat bersifat kualitatif atau pernyataan tentang suatu yang menyangkut Strategi Keberlanjutan Ekonomi Masyarakat Nelayan Di Desa Masadian Kecamatan Menui Kepulauan Kabupaten Morowali. Sumber data sekunder adalah data yang diperoleh secara tidak langsung dari informan penelitian, tetapi data diperoleh dari hasil studi dokumentasi. Data tertulis, foto dan literatur-literatur yang berhubungan dengan penelitian.

Teknik pengumpulan data yang digunakan oleh penulis dalam penelitian ini adalah Wawancara mendalam (in depth interview), Nazir (2011) mengemukakan bahwa : wawancara adalah proses memperoleh keterangan untuk tujuan penelitian dengan cara Tanya jawab sambil bertatap muka antara penanya atau pewawancara dengan si penjawab atau responden dengan menggunakan alat yang dinamakan interview guide (pedoman wawancara). Wawancara tersebut bertujuan memperoleh secara detail dan lebih jelas mengenai peran masyarakat nelayan dalam keberlanjutan ekonomi di Desa Masadian Kecamatan Menui Kepulauan Kabupaten Morowali, Pengamatan (observasi) atau kegiatan keseharian manusia dengan menggunakan panca indra, mata sebagai alat bantu utamanya selain panca indra lainnya seperti telinga, mulut dan kulit. Yang dimaksud metode observasi adalah metode pengumpulan data yang digunakan untuk menghimpun data penelitian, datadata penelitian ini dapat diamati oleh peneliti. Dalam arti bahwa data tersebut dihimpun melalui penggunaan panca indera. Pengamatan yang dilakukan peneliti adalah mendatangi lanngsung ke lokasi penelitian, kemudian mengamati proses kegiatan di pantai yang berkaitan dengan nelayan tangkap pada nelayan di Desa Masadian, dan Studi Dokumentasi yangditujukan untuk memperoleh data sekunder dan informasi yang dapat memperkaya penelitian ini. Data dan informasi tertulis ini diperoleh dari literatur, dokumen yang ada tentang informan mengenai Peran Masyarakat Nelayan Dalam Keberlanjutan Ekonomi Di Desa Masadian Kecamatan Menui Kepulauan Kabupaten Morowali.

Data yang dikumpulkan dalam penelitian ini akan di analisis secara deskriptif kualitatif yaitu semua sumber data yang diperoleh dilapangan dikumpulkan dan kemudian ditarik kesimpulan berdasarkan jawaban-jawaban dari informan yang relevan dengan masalah-masalah dalam penelitian ini. Untuk data primer lebih dahulu dilakukan tabulasi data dan analisis presentase guna mengetahui kecenderungan (data koesioner) dan data kategorisasi/edit (data wawancara dan pengamatan), untuk selanjutnya diinterpretasikan atau dikualitatifkan. Hal ini juga dilakukan untuk data sekunder.

\section{HASIL DAN PEMBAHASAN}

Berdasarkan hasil penelitian yang didapatkan pemecahan masalah keberlanjutan ekonomi masyarakat Desa Masadian menggunakan strategi aktif dimana semua masyarakat mengungkapkan dalam pemenuhan kebutuhan sehari-hari dengan melakukan kerja sampingan dengan berbagai macam bentuk pekerjaan seperti bekerja sebagai buruh bangunan, buruh pembuatan kapal/perahu, pembeli ikan. Pekerjaan sampingan yang paling banyak dipilih oleh nelayan adalah buruh bangunan 
dan buruh pembuat kapal. Hal ini disebabkan Desa Masadian merupakan satu-satunya desa di Kecamatan Menui Kepulauan yang berbatasan dengan desadesa pesisir lainnya yang ada di kecamatan menui kepulauan sehingga nelayan setempat selain melakukan kegiatan penangkapan juga melakukan pembuatan kapal/peruhu untuk dijual di desa tetangga, sedangkan buruh bangunan kebanyakan masyarakat menyebar di desadesa lainnya di Kecamatan Menui Kepulauan bahkan sampai di desa-desa di kecamatan lain di Kab. Morowali.Pekerjaan selanjutnya yang ditekuni oleh nelayan adalah menjadi pembeli ikan. Hal ini disebabkan oleh masih luasnya hamparan tanah di Desa Masadian.Kemudian masyarakat juga menggunakan strategi pasif dengan mengurangi pengeluaran dan dapat mengimbangi pendapatan keluarga dengan cara membatasi pembelian barang-barang mahal dan mengurangi konsumsi sayur mayur yang harganya mahal pula seperti kol, sawi dan lain-lain. Kemudian strategi terakhir membangun relasi dengan meminjam uang/modal untuk membangun usaha kecil-kecilan guna mempertahankan hidup. Sebagian besar masyarakat meminjam uang untuk usaha warung sembako di instansi koperasi simpan pinjam dengan resiko-resiko peminjaman yang tinggi, dengan demikian solusi untuk pemecahan masalah tentang bertahan hidup dapat tertasi.

Problematika tentang kemiskinan ditengah masyarakat memerlukan usaha sadar setiap masyarakat atas keterlibatannya dalam menanggulanginya. Hal ini harus melibatkan banyak pihak tidak hanya dari anggota keluarga Desa Masadian tetapi jutru pemerintah harus turut andil dalam membantu mengatasi kemiskinan. Untuk menanggulangi kemiskinan secara garis besar di kenal dua pendekatan yaitu, kebijaksanaan yang bersifat tidak langsung dan bersifat langsung. Pendekatan pertama melalui pembangunan ekonami nasional yang berorientasi pasar yang sehat di tingkat nelayan. Pendekatan ini dapat berupa atau terkait dengan program pemerintah secara sektoral seperti pendidikan, kesehatan, prasarana, dan bentuk bantuan langsung pada kelompok miskin. Di satu sisi model penanggulangan kemiskinan memperkuat lembaga-lembaga ekonomi masyarakat di tingkat desa/kelurahan dengan menetapkan koperasi serba usaha dan warung-warung atau kios-kios serba ada. Di desa Masadian dengan berdasarkan hasil penelitian bahwa model penanggulangan kemiskinan dengan pendekatan partisipatifatau peran istri/anak untuk membantu suami bekerja.

\section{KESIMPULAN}

Berdasarkan uraian dari hasil penelitian dan pembahasan yang telah dilakukan, maka peneliti dapat menarik kesimpulan, meliputi:

1. Strategi yang digunakan masyarakat Desa Masadian di dalam penghidupannya dapat dibagi tiga yaitu: strategi aktif, strategi pasif dan strategi jaringan.

2. Strategi aktif yaitu mengoptimalkan segala potensi keluarga untuk mengatasigoncangan

ekonomi dengan menambah jam kerja dari biasanya karena tuntutan hidup yang semakin besar. Penambahan kerja tersebut adalah kerja sampingan artinya pekerjaan selain pekerjaan utamanya/pokok.

3. Strategi pasif yaitu mengurangi pengeluaran keluarga misalnya pengeluaran pangan dan sandang dan biaya pendidikan. 
4. Strategi jaringan seperti menjalin relasi, baik formal maupun informal dengan lingkungan sosialnya dan lingkungan kelembagaan misalnya: [meminjam uang tetangga, menghutang di warung, memanfaatan program kemiskinan, meminjam uang pengusaha ikan, dan badan usaha miliki desa (BUMDES ).

5. Rumah tangga nelayan dapat dianggap sebagai suatu kesatuan ekonomi yang tersusun dari individu-induvidu dengan seperangkat aturan ekonomi yang dipatuhi bersama dan saling bertanggung jawab serta saling berhubungan secara fungsional. Di Desa Masadian model penanggulangan kemiskinan dengan pendekatan partisipatif atau peran istri/anak untuk membantu suami bekerja agar keberlangsungan hidup sehari-hari terpenuhi.

\section{DAFTAR PUSTAKA}

Agus, Apun, Budhiman., Hary, Christijanto., Siti., Kamarijah, Ganef, Hari, Budoyo. (2010) Penentuan Insikator Pendekatan Ekosistem Dalam Pengelolaan Perikanan (Ecosystem Approach to Fisheries Management). Bogor: Direktorat Sumberdaya Ikan, Direktorat Jenderal Perikanan Tangkap, Kementerian Kelautan dan Perikanan, WWFIndonesia danPusat Kajian Sumberdaya Pesisir dan Lautan Institut Pertanian Bogor.

Arifin, Rudyanto (2004) Kerangka Kerjasama dalam Pengelolaan Sumberdaya Pesisir dan
Laut. Jakarta: Bappenas. Berkes

Christanto, 2010. Pengantar Pengelolaan Berkelanjutan Sumberdaya Wilayah Pesisir dan

Pulau-Pulau Kecil. Yogyakarta: Deepublish.

Carlssona, Lars \& Berkesb Fikret. (2005) Pengelolaan bersama: konsep dan implikasi metodologis. Jurnal Manajemen Lingkungan

Dahuri, Rokhmin, Dkk. 2001. Pengelolaan Sumberdaya Wilayah Pesisir dan Laut Secara

Terpadu. edisi ke-3Penerbit PT. Paradnya Paramita, Jakarta.

Edi Suharno 2003 dalam Syuryani 2017. "Strategi Bertahan Hidup Rumah Tangga Nelayan

Tradisional Dalam Mengatasi Kemiskinan.

Merta, I. G. S., S. Nurhakim, dan J. Widodo. 1998. SumberdayaPerikananPelagis Kecil dalamPotensidanPenyebaran SDI Laut di Perairan Indonesia.hal 89-96

Muluk, Alains., Seprianti Eka Putri., Prilia Haliawan. (2009) Pengelolaan Sumberdaya Perikanan Berbasis Masyarakat (PSPBM) melalui Model Co-Management Perikanan.Jurnal Ekonomi Pembangunan 10(2), 172 198

Naamin, N. 1991.Petunjuk Teknis Pengelolaan Perairan Laut dan Pantai Bagi Pembangunan Perikanan. Seri Pengembangan Hasil Penelitian Perikanan No. PHP/KAN/PT.19/1991. Puslitbang Perikanan Jakarta.80 hal.

Nasir Moh. 2011. Metode Penelitian. Ghalia Indonesia.Bogor. 
Nikijuluw, V. P. H. 2002. Rezim Pengelolaan Sumberdaya Perikanan. P3R dan PT. Pustaka

Cidesindo.Jak-sel. 254 hal.

Olaoye, O. J., A. A. Idowu, G. A. K. Omoyinmi, I. A. Akintayo, O. C. Odebiyi and Fasina. 2012. SocioEconomic Analysis of Artisanal Fisher Folks in Ogun Water-Side Local Government Areas of Ogun State, Nigeria, Global Journal of Science Frontier Research Agriculture and Biology. USA. Volume 12 Issue 4 Version 1.0

April 2012.

Ruslan Ahmad. 2014. Metodologi Penelitian Kualitatif. Ar-Ruzz. Media. Yogyakarta.

Rahim, A. 2010. Analisis Harga Ikan Laut Segar dan Pendapatan Usaha Tangkap Nelayan di Sulawesi Selatan, Disertasi. Program Studi Ekonomi Pertanian. Fakultas Pertanian Universitas GadjahMada. Jogjakarta 